\title{
DOKTRYNA SYNODU
}

\section{I. ŹRÓDEA I CELE}

II Sesja Synodu Biskupów, jak stwierdza Schemat przygotowawczy, była sesją nadzwyczajną (coetus extraordinarius) ${ }^{1}$. Oznacza to między innymi, że zaistniały powody, które ją w mniejszym czy większym stopniu spowodowały, czy $\mathrm{w}$ każdym razie warunkowały. Schemat, a zwłaszcza Relacja do jego pierwszego rozdziału przedstawiona przez kardynała Sepera, powód ten upatruje przede wszystkim we wzroście poczucia odpowiedzialności za życie wiernych ${ }^{2}$. Ta sama Relacja wymienia dwa jeszcze inne powody zwołania Synodu i poświęcenia go sprawie kolegialości, mianowicie pietyzm wobec dziedzictwa II Soboru Watykańskiego i płynąca ze zmieniających się szybko warunków, paląca potrzeba adaptacji instytucji kościelnych do wymogów życia ${ }^{3}$. Ten zestaw przyczyn, $z$ jednej strony stanowi jedyne właściwie konkretne wyjaśnienie i uzupełnienie charakteru nadzwyczajności Synodu, a z drugiej ukazuje, że Synod ten nie był wynikiem działania czynników doraźnych, przejściowych, małoznaczących, czy tym bardziej prestiżowych ale efektem doniosłych procesów działających wewnątrz Kościoła i jego życia.

W ścisłym związku z przyczynami Synodu i określoną jego tematyką pozostaje cel i zadanie, które zostały mu wyznaczone przez pa-

1 „Episcopi Synodo primum in coetum extraordinarium congregandae...”, Schemat (= Schema de quo disceptabitur in primo extraordinario coetu Synodi Episcoporum secundum Conferentiarum Episcopalium animadversiones exaratum), Typis Polyglottis Vaticanis, 1969, s. 5.

${ }_{2}$,Maior enim in dies „,corresponsabilitas” suscitatur tum apud pastores locales tum apud totam christifidelium multitudinem circa operosam participationem in mutuo expendendis et solvendis gravioribus quaestionibus, quae hodie Ecclesiae vitam magnopere agitant", Relatio de parte doctrinali, Typis Polyglottis Vaticanis, 1969 , s. 5 .

3 Tamże. 
pieża. Stanowi je - zdaniem kardynała Sepera, komentującego Schemat przygotowawczy - pragnienie zacieśnienia więzów skutecznej współpracy duszpasterskiej między różnymi ogniwami życia kościelnego ${ }^{4}$, wysiłek zmierzający do znalezienia nowych dróg praktycznego urzeczywistnienia kolegialnej troski biskupów o cały Kościól, określonej nowatorsko affectus collegialis ${ }^{5}$, a wreszcie troska o wzmożenie jedności i miłości kolegium biskupiego $z$ papieżem jego głową ${ }^{6}$. W sumie, zamierzenia Synodu miały raczej charakter praktyczno-duszpasterski i skupiać się miały przede wszystkim na znalezieniu konkretnych form realizacji zaangażowania kolegialnego episkopatu wobec całego Kościoła w oparciu o ustalone dotąd teoretyczne i bezsporne tezy kolegializmu ${ }^{7}$.

Program zawarty w Schemacie, konsultowany uprzednio z konferencjami biskupów ${ }^{8}$, obejmował krótki, teoretyczny dyskurs nad doktryną o kolegialności, następnie zagadnienie zacieśnienia stosunków między konferencjami biskupów a Stolicą Apostolską (De arctiore coniunctione inter Episcoporum Conferentias et Sedem Apostolicam), a wreszcie sprawę ściślejszej współpracy między konferencjami biskupów (De arctiore coniunctione inter ipsas Episcoporum Conferentias).

\section{ROZDZIAE DOKTRYNALNY}

\section{Doktryna Schematu i Relacji}

W rozdziale teoretycznym, stanowiącym pierwszą część Schematu chodziło przede wszystkim o to, by dwa następne kompleksy zagadnień o charakterze praktyczno-duszpasterskim osadzić na gruncie rozstrzygnięć pierwszego i drugiego Soboru Watykańskiego, dotyczących nauki o prymacie i kolegialności biskupów. Rozstrzygnięcia te, ustalające

4 ,...ut omnium membrorum Ecclesiae vera virium conspiratio in bonum commune stabiliatur", tamże.

5 ,... ut novae etiam aperiantur viae, quibus sollicitudo Episcoporum de universa Ecclesia eorumque affectus collegialis ad concretam applicationem perducantur", tamże.

6 ,... ut unitas membrorum Collegii Episcoporum cum Romano Pontifice, Collegii Capite, in exercenda sollicitudine pastorali Ecclesiae efficacior redderetur", tamże, ss. $5-6$.

7 Tamże.

8 ,... de quo (argumento Synodi, dop. S. N.) tempestive ipsae etiam Episcoporum Conferentiae suam mentem iam manifestarunt", tamże, s. 6.

9 Relacja, pomyślana jako wyjaśniająca prezentacja treści odnośnego rozdziału Schematu przygotowawczego, w zasadzie nie odbiega od jego treści. Wątpliwości, jakie w tej mierze wysunęli niektórzy uczestnicy Synodu pod adresem zwłaszcza rozdziału I, mają swoje główne źródło w tym, że Relacje treść ujmują w sposób bardziej przejrzysty i wyczerpujący. 
sprawy pozornie antagonistyczne, w rzeczywistości mogą i muszą zostać ze sobą zharmonizowane, gdyż w samej rzeczy stanowią elementy wzajemnie się uzupełniające $\mathrm{w}$ ramach jednego doniosłego członu istoty Kościoła, jakim jest pierwiastek kościelnego, hierarchicznego zwierzchnictwa. Wyczuwa się w tym rozdziale wyraźną troskę, aby doktrynę o kolegialiźmie utrzymać jak najbardziej wiernie w nurcie tego, co zostało uroczyście ustalone dotąd, z góry definiując ewentualność jakiegoś nowego czy zmodyfikowanego jej ujęcia.

Rozdział doktrynalny składa się $\mathrm{z}$ trzech wymownie zatytułowanych paragrafów: 1. de christifidelium communione, 2. de Episcoporum communione, 3. de Episcoporum collegiali activitate.

Paragraf pierwszy stanowi ogólny zarys perspektywy, w której Schemat pragnie umieścić i rozpatrywać naukę o kolegialności. Perspektywą tą jest ujęcie Kościoła jako wspólnoty zamierzonej przez Boga od wieków, a zrealizowanej przez Chrystusa w postaci nowego, mesjańskiego Ludu Bożego, będącego sakramentem podwójnej jedności ludzi między sobą i Bogiem. Dziwna ta wspólnota, określona jako totum quid orgaricum et vivens, polega $\mathrm{z}$ jednej strony na posiadaniu przez odkupionych Krwią Chrystusa udziału w nadprzyrodzonych dobrach, stanowiących uczestnictwo $\mathrm{w}$ tajemnicy Chrystusa, a $\mathrm{z}$ drugiej na szeregu rzeczywistości religijnych, przyjmujących także postać wyraźnych struktur społecznych, czynnie zaangażowanych $\mathrm{w}$ rzeczywistym zrealizowaniu się i widzialnym ujawnieniu się tej wspólnoty ${ }^{10}$.

Wspólnota ta obejmuje więc dwa wyraźnie różniące się pierwiastki widzialny (wyznanie wiary, sakramenty, hierarchia) i niewidzialny (dary Ducha św., cnoty boskie), które jeảnak nie tylko są ze sobą jak najściślej powiązane, ale wzajemnie się warunkują w swoim istnieniu, tak, ,że w wypadku zabraknięcia zewnętrznych pierwiastków, wspólnota nie może być społecznie zrealizowana ${ }^{11}$. Ten ścisły i organiczny związek obydwu elementów wspólnoty kościelnej idzie tak daleko, że staje się ona rzeczywistością sakramentalną, w której to co widzialne, wyraża i sprawia to co niewidzialne, stając się narzędziem wewnętrznej łączności ludzi z Bogiem i jedności całego rodzaju ludzkiego" 12.

W ramach tej szerokiej wspólnoty Kościoła działa druga, węższa, inne totum quid organicum et vivens, jakim jest kolegium biskupie, będące $\mathrm{w}$ posiadaniu otrzymanej przez sakrę biskupią pełni otrzymanego przez Chrystusa posłannictwa apostolskiego, umożliwiającego dostęp do zbawczej tajemnicy Chrystusa przez wykonywanie funkcji nauczycielskich, kapłańskich i zwierzchnich ${ }^{13}$. Wspólnota ta, a więc organicznie

10 Por. Schemat, s. 8, Rel., ss. 7, 9 nn.

11 Rel. I, s. 8.

12 Rel. I, ss. 8-9. Por. Konstytucja Lumen Gentium, I, nr 1.

13 Por. Rel. I, ss. 9-11. Godnym podkreślenia jest fakt, że temu właśnie zagad- 
powiązany zespół, jest autentyczną kontynuacją i spadkobierczynią grona apostolskiego, co $z$ jednej strony wskazuje na jej wyjątkowe znaczenie w życiu Kościoła, ale $\mathrm{z}$ drugiej podlega tym samym prawom i zasadom, jakie obowiązywały i normowały strukturę kolegium apostolskiego. Struktura ta dziedziczona przez kolegium biskupów z papieżem na czele, jest następstwem sakramentalnej wspólnoty jej uczestników, mającej z kolei swoje źródło $\mathrm{w}$ będącej sakramentem sakrze biskupiej, która zapewnia udział w Chrystusowym kapłaństwie ${ }^{14}$. Wspólnota biskupia stanowi i podstawę biskupiej działalności i wyznacznik ścisłej łączności, jaka istnieje między samymi biskupami i między nimi i papieżem; słowem, stanowi czynnik o decydującym znaczeniu dla działalności każdego biskupa na terenie własnego Kościoła. Choć bowiem ważnie wyświęcony biskup posiada ontologiczne uprawnienia do pełnienia posłannictwa biskupiego, to aktualizacja tych funkcji uwarunkowana jest zgodą wspólnoty i rzeczywistą z nią i z jej głową harmonią ${ }^{15}$. Nietrudno zauważyć, że czynnik wspólnoty kolegium biskupiego został w Schemacie i towarzyszącej jej Relacji dobitnie wyeksponowany, czego wyrazem jest zakwalifikowanie go jako tamquam elementum constitutivum Christi Ecclesiae ${ }^{16}$. W rzeczy samej ma on decydujący wpływ na profil widzialnej struktury Kościoła, a z drugiej strony tak zasadniczo warunkuje pasterską działalność biskupa w skali Kościoła partykularnego i powszechnego. Toteż nic dziwnego, że tak Schemat, jak Relacja dokładają starań, by możliwie jak najdokładniej wyjaśnić dialektykę funkcjonowania wspólnoty hierarchicznej. Wychodzą bowiem z jak najbardziej słusznego założenia, że ta właśnie struktura dialektyki warunkuje zarówno harmonijne współdziałanie prymatu i episkopatu, jak też prawidłowo rozwijające się stosunki poszczególnych episkopatów w ramach realizowania kolegialności.

W ujęciu więc Relacji ${ }^{17}$, funkcjonowanie wspólnoty hierarchicznej, mającej tak doniosłe znaczenie dla struktury Kościoła, w przeszłości kształtowało się w różnoraki sposób. „Zachowując bowiem samą zasadę wspólnoty hierarchicznej w Kościele, praktyczna realizacja wzajemnego uwarunkowania posłannictwa papieskiego i posłannictwa reszty biskupów tak wobec Kościoła powszechnego, jak wobec Kościołów partykularnych,

nieniu poświęcił wnikliwą wypowiedź J.E.X. Kard. K. Wojtyła. Jej tekst zamieszczono gdzie indziej powyżej, ss. 153-155.

14 ,In consecratione enim episcopali Episcopi illam specificam participationem unius Christi sacerdotii tamquam donum Spiritus Sancti collatam recipiunt qua Christo Domino particulari modo ac per Ipsum inter se uniuntur atque Domino ita consecrati et configurati Eius muneris Gregem Dominicum pascendi participes fiunt", Rel. I, s. 13.

15 Tamże, ss. $13-14$.

16 Tamże, s. 14.

17 Treść Relacji w tym miejscu poważnie dystansuje odnośną treść Schematu, 
W ciągu wieków podlegały poważnym zmianom" ${ }^{18}$. Prowadzi to do logicznego wniosku, że w praktycznej realizacji wspólnoty hierarchicznej, wyróżnić trzeba - założywszy oczywiście nienaruszalność praw prymatu - elementy istotne i dlatego stałe i niezmienne, oraz takie, które warunkowane są okolicznościami i stąd nanoszone przez historię. To zaś stawia wobec konieczności oddzielenia jednych od drugich, żeby w prawidłowy sposób odpowiedzieć wymogom chwili w zakresie praktycznego zaangażowania wspólnoty hierarchicznej w życiu Kościoła ${ }^{19}$. I to również stanowi jedno $\mathrm{z}$ głównych zadań Synodu.

Jednym z najważniejszych odcinków aktywności wspólnoty hierarchicznej jest zaangażowanie biskupów w pasterskiej trosce o cały Kościół i związana z tym rola papieża w realizacji owego zaangażowania, wraz z wynikającymi stąd wzajemnymi stosunkami kolegium i jego głowy. Zagadnienia te stanowią treść trzeciego paragrafu rozdziału doktrynalnego ${ }^{29}$.

Gdy Schemat rozpoczyna swój wykład od powtórzenia nauki II Soboru Wałykańskiego o najwyższej władzy papieża nad całym Kościołem i płynącej stąd roli ,zasady widzialnej koordynacji i kierowania całej działalności Kościoła" a co za tym idzie roli gwaranta jedności kolegium biskupiego ${ }^{21}$, to Relacja wychodzi od stwierdzenia wspólnej choć zróżnicowanej troski i odpowiedzialności Apostołów i Piotra za pasterskie kierownictwo Kościolem i wynikającej stąd potrzeby właściwego wywiązania się z ciążących na nich obowiązków, ale przede wszystkim od zaake€ntowania wspólnego udziału papiestwa i episkopatu w zapewnieiliu Kościołowi jedności, oczywiście modo cuique proprio, vi peculiaris missionis ab ipso Domino ipsis concreditae ${ }^{22}$. Ponieważ udział prymatu i episkopatu w życiu Kościoła wiąże się z istotnymi jego przymiotami, jakimi są jedność i powszechność, jest rzeczą zrozumiałą i konieczną

tak z tytułu większej jasności jak zwłaszcza ze względu na bardziej wyczerpujące i oryginalne ujęcie sprawy praktycznej realizacji zasady kolegialności w aspekcie historycznym. Schemat ogranicza się bowiem właściwie jedynie do zacytowania nauki zawartej w Lumen Gentium, tymczasem Relacja choć również stanowczo nawiązuje do tej nauki, to przecież naukę tę usiłuje również wyraźnie w niektórych elementach uzupełnić.

18 Rel. I, s. 14.

19 Tamże, ss. $14-15$.

${ }^{20}$ W Schemacie artykuł ten zatytułowany jest: De Episcoporum collegiali activitate, podczas gdy w Relacji tytul ten brzmi: De collegiali Episcoporum opere, a całość artykułu podzielona jest na trzy paragrafy pod wymownymi tytułami: De peculiari munere Collegii et sui Capitis; De natura et exercitio potestatis supremae Ecclesiae; De Episcoporum collegiali activitate in Ecclesia.

21 Schemat, s. 10.

22 „Christus Dominus Ecclesiam suam et Petro et ceteris Apostolis diversimode sed indissolubiliter unitis pascendam concredidit. In hac mutua relatione Petri et ceterorum Apostolorum, utraque pars suum proprium munus implendum habet. Tum Supremo Pastori tum Episcopis cunctis munus visibiliter firmandi Ecclesiae unitatem competit, sed modo cuique proprio vi peculiaris missionis, ab ipso Domino concreditae", Rel. I, s. 16. 
zastosowanie właściwej równowagi i dyktowanych strukturą jednego i drugiego proporcji. W przeciwnym razie albo jednośé, alko powszechność mogłyby ulec zagrożeniu. Stróżem i promotorem tej równowagi jest papież, który z natury swego urzędu z całkowitą swobodą wykonuje swoje najwyższe zwierzchnictwo w Kościele ${ }^{23}$. Od papieża również ostatecznie zależy, czy i kicdy wspólnota hierarchiczna działać będzie w Kościele kolegialnie, (czyli cały episkopat z papieżem) czy personalnie (a wie papież sam) ${ }^{24}$. Relacja zdecydowanie odrzuca jako błędną opinię, że papież działający indywidualnie jest wyizolowany od kolegium, podając jako rację fakt, że papiestwo zawsze działa w Kościele i dla dobra Kościoła i dlatego nigdy nie może być oddzielone i od kolegium ${ }^{25}$.

Wyjątkowa jednck pozycja urzędu papieskiego w realizacji pasterskiej troski wspólnoty hierarchicznej w stosunku do całego Kościoła, wyrażająca się w podejmowaniu decyzji o dzialalności kolegialnej czy personalnej i określeniu warunków realizacji tej pierwszej ${ }^{26}$, nie oznacza bynajmniej działania niczym nieskrępowanego, kierowanego racjami czysto subiektywnymi i arbitralnymi. Przeciwnie, cała ta niezmiernie ważna i odpowiedzialna działalność papieska, kierować się musi jak najbardziej obiektywnymi normami, które stanowią Słowo Boże i dobro Ludu Bożego oraz Tradycja pierwotnego Kościoła. Normy powyższe, rzecz jasna konfrontowane być muszą z aktualną a więc różniącą się w poszczególnych okresach historycznych sytuacją w Kościele i co za tym idzie, dyktują różne rozstrzygnięcia w sprawie potrzeby i sposobów kolegialnej działalności kolegium kiskupiego ${ }^{27}$.

Z kolei tak Schemat, jak i Relacja charakteryzują sposoby w pełni kolegialnej i, jeśli tak można powiedzieć, parakolegialnej działalności w Kościele, umieszczając u podstaw tego działania wspomnianą już postawę kolegialną, czy może lepiej ,odczucie kolegialne” (affectus collegialis) członków kolegium biskupiego. Stanowi je coś w rodzaju instynktu odpowiedzialności biskupów za cały Kościół, instynktu który domaga się ustawicznego zaspokojenia $\mathrm{w}$ konkretnym działaniu kolegialnym. Instynkt taki jest jak najbardziej właściwy, ale jego pełne zaspokojenie nigdy nie bẹdzie możliwe, zostawiając na zawsze ewentualność powstawania nowych sposobów realizacji aktywności kolegialnej. Nic więc dzi-

23 Tamże.

24 ,Cum igitur Successoris Petri iudicium profecto spectet determinare modum quo hanc sollicitudinem pastoralem in actum deduci conveniat, scilicet sive modo personali sive modo collegiali...", Schemat, s. 10.

25 Por. Rel. I, s. 18.

26 Por. Konstytucja dogmatyczna o Kościele Lumen Gentium (= KK), III, nr 22.

27 Por. Rel. I, s. 18. - Godne podkreślenia jest to, że doniosła wzmianka o normach obowiązujących papieża w kierowaniu działalnością kolegialną episkopatu, tak wyraziście wystąpiła po raz pierwszy w oficjalnych dokumentach kościelnych. 
wnego, że za Schematem Relacja stwierdza lapidarnie, iż „fakt odczucia kolegialnego ma zasięg znacznie szerszy, aniżeli rzeczywista działalność kolegialna" 28.

Tak zwana ściśle kolegialna działalność episkopatu, polega na autorytatywnym zaangażowaniu całego kolegium biskupiego $z$ papieżem jako głową w stosunku do całego Kościoła ${ }^{29}$. Relacja, idąc za Konstytucją o Kościele i Schematem, określa bliżej rolę papieża w powstawaniu tej ściśle kolegialnej działalności, wyliczając trzy sposoby jej realizacji (wezwanie, zatwierdzenie, przyjęcie) i zwraca uwagę, że wachlarz tych inicjatyw papieskich zmierzających do kolegialnego uaktywnienia episkopatu, jest szeroki i zróżnicowany, nigdy jednak nie może on poddać w jakąś ludzką zależność zwierzchności papieskiej ${ }^{30}$.

Drugi typ działalności kolegialnej, która została określona jako parakolegialna, reprezentuje przede wszystkim instytucja Synodu. Obydwa dokumenty wprowadzające, wnikliwie charakteryzują źródła, strukturę i przeznaczenie Synodu, odwołując się raz po raz do podstawowego w tym względzie dokumentu, jakim jest Motu proprio Apostolica Sollicitudo z dnia 15 września 1965. Synod, zdaniem Schematu, stanowi dobitny i skuteczny przejaw pasterskiej troski biskupów, pasterzy lokalnych Kościołów, o dobro Kościoła powszechnego ${ }^{31}$. Relacja uzupełnia ten Schemat stwierdzając, że Synod przez zaangażowanie ogólnokościelne biskupów, stanowi skuteczny środek ściślejszego zacieśnienia i ukazania więzów jedności, istniejącej między episkopatem a Najwyższym Pasterzem Kościoła ${ }^{32}$. Relacja nawiązuje tu wyraźnie do tego, co wspomniane wyżej Motu proprio mówi na ten temat jednego z głównych celów Synodu Biskupów ${ }^{33}$. Okoliczność, że Synod jest zebraniem reprezentującym cały episkopat sprawia, że trzeba zaszeregować go do działalności, która „,bardzo zbliża się do działania kolegialnego w ścisłym tego słowa

28 Schemat, ss. 10-11; Rel. I, s. 19.

29 Choć ani Schemat, ani relacja nie usiłują dokładnie definiować ściśle kolegialnego działania episkopatu, to przecież obydwa dostarczają danych, aby taką definicję stworzyć. Por. Schemat, s. 11; Rel. I, s. 19. Obydwa również dokumenty sygnalizują różnorodne przejawy kolegialnej odpowiedzialności biskupów za cały Kościół, realizującej się we wspóldziałaniu z papieżem, dzieląc je na: a). uczestniczenie w pasterskim kierowaniu całym Kościołem, realizującym się we wielorakich relacjach biskupów z papieżem (apelacje do Rzymu, Synody, Sobory, sondaże w sprawach doktryny) oraz b). ścisłą działalność kolegialną, jakiej przykładem jest Sobór powszechny. Por. Schemat, s. 11; Rel. I, s. 19.

30 Por. Rel. I, s. 19; KK, III, nr 22.

31 ,Episcopalis Synodi institutio novam quandam viam activitatis collegialis Episcoporum pro tota Ecclesia in exercitio eorum sollicitudinis pastoralis pro Christi Grege aperit... per quam Ecclesiarum localium Pastoribus copia datur ,manifestiore efficacioreque ratione participandi sollicitudinem" Supremi Pastoris in bonum Ecclesiae universae...", s. 11. Por. Rel. I, ss. 19-20.

$32, \ldots$ hoc modo vincula communionis inter Supremum Ecclesiae Pastorem et Episcopos per mutuam cooperationem et coordinationem curae pastoralis arctius astringuntur atque luculentius demonstrantur", s. 20.

33 Por. Synodus Episcoporum, Romae, 1969, s. 3. 
znaczeniu ${ }^{34}$. Jak widać dokumenty przygotowawcze, choć uznały w Synodzie ,instytucję stałą i z natury swojej wiecznotrwałą w Kościele", choć przyznały mu szereg pierwiastków prawdziwego aktu kolegialnego (troska o cały Kościół, reprezentacja całego episkopatu, łączność z papieżem i jego wezwanie), to przecież wyraźnie uchyliły się od przypisania mu wysokiej rangi działania ściśle kolegialnego. Nazywa się go wejściem „na nową drogę aktywności kolegialnej” ${ }^{35}$, ale równocześnie wyraźnie odróżnia się go od klasycznego aktu kolegialnego, jakim jest Sobór, podkreślając, że jest tylko czymś zbliżonym do niego ${ }^{36}$. Czynnikiem, którego zabrakło Synodowi, aby można było przyznać mu cechę ścisłej kolegialności, jest zobowiązujący, autorytatywny charakter jego decyzji. Dopiero wtedy bowiem biskupi na Synodzie występowaliby jako prawdziwi zwierzchnicy całego Kościoła. Takie decyzje może wprawdzie Synod podejmować sporadycznie, ale zawsze tylko w wyniku wyraźnego, szczególnego upoważnienia papieża ${ }^{37}$, jednak nie odbiera to nadanego mu od początku charakteru organu doradczego, który zresztą wyraźnie został podtrzymany w odniesieniu do obecnego Synodu $\mathrm{w}$ dokumentach przygotowawczych ${ }^{38}$. Co prawda, niedwuznacznie stwierdzono możliwość jego ewolucji w kierunku ścisłej kolegialności ${ }^{39}$, ale jest to ciągle tylko perspektywa przyszłości. Obecnie zaś Synod, prócz wspomnianych już wyżej funkcji przyczyniania się do zwiększania spoistości kościelnego zwierzchnictwa, ma służyć nadal dla celów informacyjnych i doradczych, a więc do wspomagania papieża przez dostarczanie miarodajnych wiadomości o życiu całego Kościoła oraz opiniowanie koniecznych dla tego życia decyzji ${ }^{40}$. Nie od rzeczy będzie wspomnieć jeszcze o trzecim głównym celu Synodu, wymienionym przez Motu proprio, a nie wzmiankowanym wyraźnie przez dokumenty przygotowawcze, jakim jest troska o jedność w zakresie doktryny i postępowanie w Kościele ${ }^{41}$.

Choć utrzymanie $\mathrm{w}$ mocy decyzji o doradczym a więc nie ściśle kolegialnym charakterze Synodu powoduje pewien niedosyt, to przecież abstrahując od jasno potwierdzonego prawdopodobieństwa ewolucji, trzeba stwierdzić, że i w tym charakterze, jaki Synod posiada dotąd, stanowi w życiu Kościoła instytucję o doniosłym znaczeniu. Ukazuje

34 Rel. I, s. 20.

35 Rel. I, s. 19; Schemat, s. 11.

36 Schemat, j. w.: ,Episcopalis Synodi institutio..., quae prope actionem stricte collegialem est...".

37 Por. Rel. I, s. 20. Tekst Relacji jest cytatem dosłownym z Motu proprio..., s. 8.

38 Por. Rel. I, s. 20. ,... ad ,,Synodum Episcoporum suapte natura munus pertinet edocendi et consilia dandi"...".

39 Por. j. W.: „Si talis est structura per Litt. Apost. „Apostolicam sollicitudinem” Synodo Episcoporum data, haec tamen permittit, ut successu temporis, perfectiorem usque formam assequi poterit"...".

40 Tamże.

41 Synodus..., s. 8. 
to zacytowany przez. relację fragment przemówienia Ojca ’́w. skierowanego do uczestników pierwszej Sesji Synodu Biskupów: „... Choć zadanie jakie ma do wykonania Synod Biskupów ma charakter doradczy, to przecież zadanie takie posiada swój ciężar gatunkowy i znaczenie tak dla nas (Papieża, dop. S. N.), którzy was na tę konsultację wezwaliśmy..., jak i dla całego powszechnego Kościoła, który uznaje was za nauczycieli, świadków i pasterzy Ludu Bó̇ego..." ${ }^{42}$. W istocie dla skutecznego i owocnego wykonywania pasterskiego zwierzchnictwa papieskiego, możliwość tak bogatej i szerokiej konfrontacji z pasterzami terenowymi, stanowi okoliczność o dużej doniosłości. Choć konfrontacja taka nie powoduje natychmiastowych rozstrzygnięć to przecież na dłuższą metę warunkuje je i kształtuje. A to z kolei wywiera bezsporny i wieloraki wpływ na całokszałt życia Kościoła.

Poza Synodem, jako przejaw niepełnej jeszcze kolegialności, dokumenty przygotowawcze wymieniają inicjatywy biskupów, zmierzające do wspólnego działania, skierowanego poza obręb pojedynczego Kościoła ${ }^{43}$. $\mathrm{Na}$ czoło wysunięte zostały konferencje biskupów zalecone przez Sobór i na skutek tego wybitnie rozwinięte na całym świecie. Ich wzajemna współpraca, a zwłaszcza stosunek do papiestwa stanowi przedmiot dalszych prac Synodu.

\section{Treść i wynik obrad}

Oficjalnego podsumowania synodalnej debaty na temat rozdziału pierwszego Schematu przygotowawczego, dokonał "sekretarz specjalny" dla debaty nad częścią doktrynalną Synodu, prof. Gregorianum O. A. Anton, ktory jak się zdaje był autorem wspomnianego rozdziału. Autor zdawal sobie sprawę $\mathrm{z}$ trudności i niebezpieczeństw podsumowania debaty, w której uczestniczyło ponad pięćdziesięciu mówców. Obawiał się zwłaszcza daleko idących uogólnień wynikających z tego możliwych uproszczeń treści wypowiedzi ${ }^{44}$. Jest to jednak nieuniknione przy tego rodzaju zadaniu. Podsumowanie zostało podzielone na trzy części; w pierwszej omówione zostały te elementy nauki o kolegialności, co do których „wszyscy Ojcowie synodalni w zasadzie zgadzali się ze sobą" omnes Patres Synodales fere concordant; w drugiej scharakteryzowane zostały te punkty, co do których panowała wyraźna rozbieżność zdań; a wreszcie $w$ trzeciej znalazły się odpowiedzi na niektóre pytania postawione przez Ojców w czasie debaty ${ }^{45}$.

42 Rel. I, j. w.

43 Schemat (ss. 11-12) w tym miejscu rzecz traktuje znacznie szerzej aniżeli Relacja (I, 21), która szersze omówienie słusznie pozostawia dwu następnym Relacjom. 44 Por. Responsiones Rev. P. Angeli Anton S. J. Secretarii specialis ad animadversiones „De parte doctrinali”, Typis Polyglottis Vaticanis, 1969, s. 5.

$45 \mathrm{~J} . \mathrm{W}$. 
Pierwsza grupa obejmuje dziesięciopunktowy rejestr, w którym znajdują się takie sprawy jak aprobata dla ujmowania kolegialności w duchu I i II Soboru Watykańskiego, a zwłaszcza w kontekście nauki o kościelnej wspólnocie razem z postulatem teologicznego jej pogłębienia, tak w skali Kościoła powszechnego jak i lokalnego ${ }^{46}$, zgoda co do praktyczno-pasterskiego charakteru Synodu, dyktującego pozostawienie skomplikowanej problematyki badaniom teologów, a skupienie się w sprawach niespornych i podjęcie tymczasowych, a więc eksperymentalnych inicjatyw zmierzających do realizacji kolegialności, z uwzględnieniem jej kontekstu dynamicznego i historycznego ${ }^{47}$. $\mathrm{Z}$ innych punktów, punkt piąty mówi o postulacie wszystkich prawie Ojców, pogłębienia i wyjaśnienia wzajemnego stosunku prymatu i episkopatu w perspektywie ,teologii stosunku Kościoła powszechnego do Kościołów lokalnych" 48, a dalej punkty: szósty - o współzależności kolegialności „,afektywnej” i „efektywnej"; ósmy o racjach dyktujących potrzebę współodpowiedzialności biskupów za cały Kościół; i dziewiąty - o kryjącej się w kolegialności zasadzie wazejmności i związanej z nią kolegialnością wstępującą i zstępującą ${ }^{49}$.

W sumie zakładając jakiś margines zrozumiałej w takich wypadkach niedokładności, można powiedzieć, że - zdaniem O. Antona - jednomyślność Ojców Synodu skupiała się wokół bezwzględnej aprobaty dla nauki Vaticanum I i II dla umiejscowienia doktryny o kolegialności w kontekście teologii kościelnej wspólnoty, wraz z teologią Kościoła powszechnego i lokalnego, oraz wokół potrzeby znalezienia praktycznych sposobów efektywnej i natychmiastowej realizacji zasady kolegialności.

O ile charakterystyka nauki ogólnie podzielanej przez uczestników Synodu jakiej dokonał O. Anton, jest dość przejrzysta i łatwo sprowadzalna do kilku zasadniczych punktów, o tyle rozbieżności w spojrzeniu Ojców na doktrynalne zasady kolegialności nie zostały przedstawione ze zbytnią precyzją i lapidarnością. I tak, jest mowa o przytłaczającej ilości Ojców (maxima Patrum Synodalium pars), postulujących „prawdziwą wolność" w wykonywaniu przez papieża najwyższego i powszechnego zwierzchnictwa kościelnego, które jednak nie tylko nie pokrywa się z instytucją absolutnej monarchii, ale realizowana być musi w zgodzie z obiektywnymi wymogami dobra Kościoła, Objawionej prawdy, Tradycji, soborów powszechnych oraz natury udzielonej przez Boga w wyniku konsekracji godności biskupiej ${ }^{50}$. Z kolei O. Anton przytacza

46 Punkt 1, 3 i 7. Ten ostatni zwraca uwagę na komplementarność nauki o prymacie i episkopacie zawartej w Vat. I i II. J. W., ss. 6-9.

47 Punkt 2 i 10 . Por. j. W., ss, 6 i 8.

48 J. W., S. 7.

49 J. W.

50 Por. j. w., ss. 8 i 9. 
postulat wyrażony ,pprzez niektórych Ojców” (a nonnullis Patribus expresse exposcitur) częstszego sięgania po działanie ściśle kolegialne i nie ograniczanie go (quoad materiam) do zbyt ciasnego obszaru tematycznego, oraz (quoad formam) do instytucji Synodu Biskupów ${ }^{51}$.

Do grupy głosów różniących się między sobą na temat I rozdziału włączył O. Anton szereg dezyderatów, jakie wielu Ojców (non pauci tamen Paters) sformułowało, odnośnie rzeczywistego zaangażowania biskupów, z papieżem na czele, w duszpasterskiej pieczy nad całym Kościołem. Oto najważniejsze z nich: głos decydujący w ważniejszych sprawach doktrynalnych i dyscyplinarnych dotyczących całego Kościoła, większa częstotliwość działania kolegialnego i wydzielenie właściwego mu terenu działania, nadanie bardziej wyraźnego kolegialnego charakteru inicjatywom przygotowanym przez Sobór Watykański II, a realizowanym przez Pawła VI, jakimi są Synod Biskupów, episkopaty konferencji krajowych, reforma Kurii Rzymskiej, poszukiwanie i wprowadzanie w czyn nowych form działania kolegialnego ${ }^{52}$.

Postulaty powyższe nie są jedyne, jakie zostały wysunięte przez uczestników Synodu w związku z rozdziałem doktrynalnym Schematu przygotowawczego. Na szczególną uwagę zasługują zastrzeżenia wysunięte przez Kardynałów Alfrinka i Döpfnera. Pierwszy zarzucił, że tekst Schematu nasycony jest zbytnio jurydyzmem, który przysłania teologiczne elementy doktryny o kolegialności ${ }^{53}$. Drugi natomiast poszedł znacznie dalej, bo zakwestionował pełną zgodność doktryny Schematu i relacji $\mathrm{z}$ nauką o kolegialności usankcjonowaną przez Vaticanum I i w rezultacie wyszedł $\mathrm{z}$ wnioskiem, by tekstów przygotowawczych nie publikować jako naukę Synodu, a cały problem poddać głębokiej teologicznej analizie. Sprzeciw Kardynała dotyczył dwu głównie punktów: braku przedstawienia ujętej w duchu Vaticanum II dogmatycznej podstawy „najwyższej działalności kolegialnej biskupów” (supremae activitatis collegialis), oraz przeakcentowanie w kolegialnym zaangażowaniu biskupów charakteru pomocniczo-doradczego w stosunku do papieża, z uszczerbkiem dla autorytatywności tego zaangażowania, wynikającej z samej natury kolegium biskupiego ${ }^{54}$.

Powyższe obiekcje podjął także kardynał Suenens dodając, że dotychczasowa praktyka życia Kościoła położyła zbytni nacisk na to, by biskupi angażowali się w życie sub Petro, a mniej cum Petro. Tymczasem zaangażowanie to winno się rozwijać $w$ oparciu o jeden i drugi człon tej słusznej zasady kolegialności ${ }^{55}$.

51 Por. j. w., s. 9.

52 Por. dz. cyt., s. 10.

53 Por. Maszynopis poligrafowany.

54 Por. Animadversiones... (tekst powielony), ss. 1-2.

55 Por. Maszynopis poligrafowany, s. 1. 
Relacjonując sumarycznie debatę synodalną na temat rozdziału doktrynalnego, nie można nie wspominać o wystąpieniach polskich Ojców synodalnych: J. E. Ks. Prymasa Wyszyńskiego i J. E. Ks. Kardynała Wojtyły. Ks. Prymas akcentował konieczność dawania przez Kośció dzisiejszej ludzkości „świadectwa wierności, jedności i głębokiego podporządkowania Stolicy Apostolskiej oraz miłości wobec Najwyższego Pasterza" ${ }^{56}$. Ks. Kardynał Wojtyła skupił się na wnikliwym omówieniu struktury wspólnoty kościelnej i biskupiej, stanowiącej podstawę i najgłębsze źródlo działalności kolegialnej biskupów.

Debatę nad pierwszym rozdziałem Schematu zakończyło głosowanie - mające oczywiście charakter czysto informacyjny - nad jednym tylko pytaniem, czy wobec postulowanej przez wielu Ojców potrzeby teologicznego pogłębienia akcentowanej przez wszystkich, doktryny Soboru Watykańskiego I i II, Ojcowie zgadzają się, ażeby zaproponowana i przedyskutowana na Synodzie doktryna o kolegialności, stała się podstawą dalszej jego pracy. Wynik głosowania był bardzo wymowny: na 136 ważnych głosów, tylko 72 (placet) bez zastrzeżeń zaakceptowało przedstawioną $\mathrm{w}$ dokumentach przygotowawczych naukę. Jeden (non placet) głos był przeciwny, a 63 (placet iuxta modum) wyrażało zgodę z zastrzeżeniami 57 .

\section{STOLICA APOSTOLSKA A KONFERENCJE BISKUPIE (KOLEGIALNOSĆ WERTYKALNA)}

\section{Doktryna Schematu i Relacji}

Treść tego rozdziału 58 i przedstawiającej go Relacji 59, rozpada się na dwa wyraźnie odcinające się człony. Pierwszy usiłuje podać racje, dla których w obecnym momencie istnieje paląca potrzeba wspólnego, zespo-

56 Por. Maszynopis poligrafowany, s. 2. Na marginesie wypowiedzi polskich Ojców synodalnych zauważyć należy, że streszczenia tłumaczenia dokumentacji synodalnej, zamieszczone w Życiu i Myśli, nr 1, 1970, dość często nie oddają wiernie rzeczywistego sensu. W szczególny sposób dotyczy to niestety wystąpień obydwu polskich Kardynałów.

57 Por. De parte doctrinali exitus manifestationis sententiae cum recensione modorum propositorum, Typis Polyglottis Vaticanis, 1969, s. 4. W ramach zaproponowanych modi najczęściej powtarzającym się postulatem było przekazanie sprawy doktrynalnego pogłębienia nauki o kolegialności, do Międzynarodowej Komisji Teologów.

58 Jego tytul specjalny brzmial: „De arctiore coniunctione Episcoporum Conferentias inter et sedem Apostolicam".

59 Relatorem tego rozdziału był Kardynał Marty arcybiskup Paryża. Tekst relacji cytowany będzie z wydanej przez Drukarnię Watykańską Relatio De arctiore coniunctione Episcoporum conferentias inter et Sedem Apostolicam, Typis Pollyglottis Vaticanis, 1969. Oprócz Relatio..., kard. Marty dostarczył jeszcze Ojcom dokument wyjaśniający tak II rozdział Schematu, jak i jego Relatio. Dokument ten również został wydrukowany jako Manifestatio et explicatio Relationis De arctiore coniunctione inter Episcoporum conferentias et Sedem Apostolicam, Polygl. Vat., 1969. 
łowego działania konferencji biskupów i Stolicy Apostolskiej. Działanie takie poza natarczywym apelem II Soboru Watykańskiego ${ }^{60}$, dyktuje społeczna struktura Kościoła, oparta na zwierzchnictwie kościelnym, składająca się z jednostkowej, najwyższej i powszechnej władzy papieża oraz zespołowej władzy kolegium biskupów, posiadających przy tym jednostkową władzę własną nad powierzonymi im Kościołami lokalnymi. Oczywistym postulatem tak ukształtowanej struktury Kościoła, jest harmonijna współpraca składających się na kościelną zwierzchność, choć widocznie odmiennych od siebie elementów ${ }^{61}$. Takie współdziałanie dyktuje również, mająca od pewnego czasu szerokie zastosowanie w nauce Kościola postulowana przez Sobór zasada pomocniczości. Zasada ta wymaga, ażeby pozostawić poszczególnym szczeblom kościelnego zwierzchnictwa do wykonania to, co jest ono w stanie wykonać w łatwy sposób ${ }^{62}$. Anektowanie przez instancje nadrzędne spraw możliwych do zrealizowania przez szczeble niższe, hamuje korzystny postęp i ogranicza zaangażowanie $\mathrm{w}$ dobro społeczności zainteresowanych szczebli, obciąża i zakłóca skuteczne kierowanie społecznością. Zdrowo jednak pojęta zasada pomocniczości, wiąże się ściśle z zasadą solidarności dyktująca, odpowiedzialność każdego szczebla za dobro całości ${ }^{63}$.

Inną racją starania się o jak najściślejszą więź między papieżem a konferencjami biskupów, jest konieczność zabiegania o skuteczną realizację w Kościele jedności w wielości. I jedna i druga należą do istotnych przymiotów Kościoła, a zapewnić je może i powinna harmonijna i prawidłowa współpraca papieża i biskupów ${ }^{64}$.

Wymienione współczynniki wzmożonej alstualności ścisłej współpracy papiestwa i episkopatu, stworzyły dla niej solidny grunt. Nic więc dziwnego, że z kolei tak Schemat, jak zwłaszcza Relacja kardynała Marty'ego przechodzą do konkretnych propozycji, zmierzających do jej realizacji. Propozycje dotyczą konkretnych środków zacieśnienia współpracy między Stolicą Apostolską a konferencjami biskupów, oraz struktury i organizacji Synodu biskupów.

Pierwszą serię otwiera dezyderat częstszych nieoficjalnych kontaktów przedstawicieli episkopatów lokalnych z papieżem, stwarzających

60 Rel. II, s. 5.

61 Rel. II, s. 6.

62 Por. Rel. II, ss. 7-8. „Principium dictum ,subsidiaritatis” ... revera requirit ne, quae ab Episcopis peragi possint ipsorum detrahatur potestati, et ut, quae ab Episcoporum Conferentiis perfici valent, ipsarum agnoscatur esse competentiae".

63 Por. Rel. II, s. 8: „Principium itaque ,subsidiaritatis” recte intellectum, ipsius Ecclesiae naturae ratione, principium solidaritatis secumfert".

64 Schemat, S. 16: „Aiiud insuper signum temporum apparet in studio consociandi intra aequos limites ea quae unitatem Ecclesiae Christi cum iis, quae diversitatem potius Ecclesiarum fovent". 
okazję do omówienia spraw dotyczących tak całego Kościoła, jak i Kościołów terenowych ${ }^{65}$.

$\mathrm{Z}$ kolei wysunięto prośbę o rozpatrzenie ewentualności uprzednich konsultacji $\mathrm{z}$ konferencjami biskupimi w związku $\mathrm{z}$ wydawaniem przez Stolicę Apostolską doniosłych dokumentów dyscyplinarnych i doktrynalnych, dotyczących całego Kościoła ${ }^{66}$. Nie dopuszcza to oczywiście ograniczenia w niczym swobody działania papieża i wolności podjęcia decyzji wedle jego uznania. Z drugiej zaś strony także biskupi odpowiedzialni za dobro Kościoła powszechnego powinni współdziałać w budowaniu jedności kościelnej ${ }^{67}$. Z reszty propozycji wymieńmy postulat dalszego zaangażowania biskupów terenowych $\mathrm{w}$ działalność kongregacji rzymskich oraz projekt stworzenia komisji biskupów, analogicznych do kongregacji rzymskich, a reprezentujących konferencje krajowe, a wreszcie projekt powołania urzędu koordynującego współpracę konferencji biskupów i urzędów Stolicy Apostolskiej ${ }^{68}$. Wreszcie trzy postulaty dotyczą podejmowania przez Stolicę Apostolską decyzji dotyczących Kościołów lokalnych, sprawy publikacji w jakimś wielojęzycznym organie centralnym, informującym o decyzjach Stolicy Apostolskiej i o ważnych decyzjach poszczególnych konferencji oraz informacji na temat życia poszczególnych Kościołów ${ }^{69}$.

Postulaty odnośnie dalszego funkcjonowania Synodu biskupów, stanowiące trzecią część rozdziału drugiego Schematu i Relacji Kardynała Marty'ego, wyraziły się w konkretnych wnioskach, zmierzających do efektywnej realizacji zasady odpowiedzialności biskupów za cały Kościół. Wnioski te postulowały powiększenie liczby uczestników Synodu, mających mandat konferencji biskupów, ustalenie stałej rytmiki Synodu (co rok, lub co dwa), możność proponowania przez konferencje tematyki obrad Synodu (nawet i podczas jego trwania), a dalej prośba o uczestniczenie Ojca św. w posiedzeniach Synodu, nie tyle żeby rozstrzygać od razu wymagające tego zagadnienia, ale bardziej dla zaakcentowania jedności pasterza Kościoła powszechnego z pasterzami Kościołów partykularnych, prośba zresztą ofiarnie spełniona przez Pawła VI ${ }^{70}$.

Druga grupa dezyderatów usiłuje wyraźnie poszerzyć zakres dotychczasowego udziału biskupów w pasterskim oddziaływaniu episkopatu

65 Por. Rel. II, ss. 10-11: „Imprimis multum arctiori Summum Pontificem inter et Episcoporum Conferentias coniunctioni prodesse videntur relationes personales ipsum Supremum Pastorem inter et Conferentias eorumque Praesides aut delegatos... Neminem fugit quantum laboris tales conventus huiusmodi idoneos esse, qui uberrimos pro actione pastorali communi fructus afferant quique coniunctionem Episcoporum cum Supremo Pastore magnopere firment".

66 Rel. II, S. 12.

67 Tamże.

68 Rel. II, ss. 12-13.

69 Rel. II, s. 13.

70 Rel. II, s. 11. 
na życie całego Kościoła. Wyrażono więc pragnienie dalszego umiędzynarodowienia Kurii, przez uczestniczenie w jej urzędach delegatów konferencji, a także ustanowienie urzędu koordynującego współpracę konferencji biskupów z Kurią Rzymską ${ }^{71}$.

Jest wreszcie nurt propozycji, które wykraczają poza sferę samych tylko rozstrzygniecc praktycznych i dotykają delikatnej sfery doktryny, a konkretnie nadrzędności prerogatyw papieskich. Zaliczyć tu można sprawę konsultacji papieża $\mathrm{z}$ biskupami przed wydawaniem ważnych dokumentów, a bardziej jeszcze stworzenie komisji konferencji episkopatów, będących odpowiednikiem Kongregacji rzymskich ${ }^{72}$. Choć jedno i drugie ma logiczne powiązanie z naturą kolegialnej aktywności biskupów, to z drugiej strony i jedno i drugie nie kształtuje się przejrzyście w perspektywie struktury prymatu i płynącej z tego pełnej swobody papieża w Kościele. Chociaż wszystkie wypowiedzi formułujące wspomniane postulaty zastrzegały się, że nie chcą w niczym uszczuplać najwyższego zwierzchnictwa w Kościele, to trudno jednak jeszcze w tej chwili powiedzieć, czy spełnienie tych postulatów nie stanowiłoby w rzeczy samej takiego uszczuplenia.

\section{Treść i wyniki debaty}

Synodalna debata na temat rozdziału II zakończona została głosowaniem nad stanowiącymi jej kwintesencję, końcowymi wnioskami. Sformułowano, jak wiadomo, razem trzynaście wniosków ${ }^{73}$. Niektóre z nich idealnie niemal pokrywają się z treścią propozycji sugerowanych przez Schemat i Relację rozdziału drugiego. Drugą grupę stanowią te wnioski, które $w$ swej zasadniczej treści wywodzą się $z$ propozycji Schematu i relatora, ale $\mathrm{w}$ swej ostatecznej redakcji zostały $\mathrm{w}$ mniejszym lub większym stopniu zmodyfikowane.

Do grupy pierwszej zaliczyć należy przede wszystkim propozycję dotyczącą zasady pomocniczości. Propozycja planuje dokładniejsze określenie zadań już to pojedynczych biskupów, już to zespolów biskupich w zakresie wpływania na życie religijne, tak pojedynczych Kościołów, jak i całych rejonów kościelnych, z uwzględnieniem oczywiście prawa i obowiązku papieża do dyktowanych okolicznościami decyzji odgórnych, zmierzających do zapewnienia ogólnokościelnej jedności ${ }^{74}$. Doniosły ten, ale równocześnie ciągle jeszcze dość mgliście rysujący się punkt, razem

71 Expositio..., s. 8, punkt 4.

72 Tamże, punkt 5 .

73 Dokonal tego sekretarz synodalny dla rozdziału drugiego Schematu przygotowawczego prof. z Luovain V. Onclin w Responsiones, Typis Polyglottis Vaticanis, 1969.

74 Manifestatio Sent. I. 
$\mathrm{z}$ ostatnim punktem dotyczącym udziału w Synodzie towarzyszących biskupom teologów, w głosowaniu zyskał stosunkowo niską ilość głosów aprobujących (około 70 procent) ${ }^{75}$. W tej samej grupie propozycji niezmienionych $\mathrm{w}$ stosunku do propozycji relatora, umieścić trzeba wniosek dotyczący konsultowania się odnośnych biskupów ze Stolicą Apostolską, przed wydaniem decyzji dotyczących ich Kościołów lub regionów kościelnych, a także wnioski dotyczące sposobu publikacji rozporządzeń Stolicy Apostolskiej, oraz współpracy Synodów Kościoła Wschodniego z konferencjami biskupów i Stolicą Apostolską ${ }^{76}$.

Pozostałe osiem punktów czerpie swoją zasadniczą inspirację ze Schematu przygotowawczego i Relacji, ale w ostatecznej postaci, albo pomijają one niektóre fragmenty projektowanych dezyderatów, albo dezyderaty te lagodzą, czy nawet modyfikują. Najbardziej interesująco w tym względzie prezentują się wnioski dotyczące współpracy Stolicy Apostolskiej z konferencją biskupów, przy podejmowaniu doniosìych dla całego Kościoła decyzji doktrynalnych i dyscyplinarnych (punkt 1) i związany z tym wniosek odnośnie kontaktów konferencji biskupów z dykasteriami Stolicy Apostolskiej (punkt 2 i 3). W pierwszym wypadku wniosek projektuje współdziałanie i pomoc episkopatu dla papieża $\mathrm{w}$ przygotowaniu ważnych decyzji doktrynalnych i dyscyplinarnych, przeznaczonych dla całego Kościoła oraz zwraca się z prośbą do Ojca św., by zachowując reguły roztropności zechciał na takie współdziałanie zezwolić. Logiczną konsekwencją pierwszej części tego wniosku jest apel do biskupów o koordynację i synchronizację swoich lokalnych, czy terenowych inicjatyw pasterskich, z wymaganiami dobra całego Kościoła ${ }^{77}$.

Nietrudno zauważyć, że tak pierwsza jak druga część, korzeniami tkwi w propozycjach Schematu i Relacji i że stanowi odbicie nurtującej katolicką społeczność opinii, że biskupi powinni zostać realnie efektywnie włączeni w proces powstawania doniosłych dla całego Kościoła decyzji papieskich. O ile jednak druga część tego wniosku dość ściśle przylega do sugestii dokumentów przygotowawczych, o tyle człon pierwszy został gruntownie przepracowany, zastępując motyw zasięgania opinii przed ważnymi aktami, znacznie bardziej ogólnym apelem o pomocną

75 Exitus Manifestationis Sententiae cum recensione modorum propositorum, s. 6.

76 Responsiones..., s. 5.

77 Por. Responsiones..., s. 5: ,,... Ut autem cum eadem libertate componatur Episcoporum quoque de universa Ecclesia sollicitudo, Ecclesiarum Orientalium Synodi et Eposcoporum Conferentiae paratas se affirmant ut in maioribus praecipue causis tractandis, praesertim in praeparandis declarationibus aut decretis quae ad fidei unitatem aut ad disciplinam in Ecclesia universa tutandam pertinent, Summo Pontifici adiutricem praestent operam, atque exoptant ut Summus Pontifex, pro Sua prudentia, hanc accipere velit collaborationem. Eandem collaborationem, communi cum Summo Pastore mente, et ipsae suis declarationibus et decretis persequentur, ita ut coniunctis cum Eodem viribus bonum Ecclesiae universae atque Ecclesiarum particularium promoveant". 
współpracę z papieżem, do maksimum uzależniając dopuszczenie takiej współpracy od woli papieża. Nie ulega wątpliwości, że w takim ujęciu, ten delikatny z punktu widzenia nieuszczuplania praw prymatu problem, nie budzi żadnych wątpliwości natury doktrynalnej. Toteż nic dziwnego, że ten ważny ale i skomplikowany wniosek zaakceptowany został przez ponad 30 procent uczestników Synodu z czterema tylko głosami negatywnymi i dwudziestoma sześcioma - placet iuxta modum ${ }^{78}$.

Podobnie rozwiązana została sprawa kontaktów między konferencjami biskupów i Urzędami Stolicy Apostolskiej. Ostatecznie wniosek ten zawiera tylko stwierdzenie o potrzebie zorganizowania wymiany między wspomnianymi instytucjami oraz stosownego sposobu komunikowania informacji skierowanych przez Urzędy papieskie do Kościołów lokalnych ${ }^{79}$.

Trzeci wreszcie zespół wniosków tego samego typu stanowią te, które dotyczą struktury i funkcjonowania Synodu biskupów. Na pierwszym miejscu umieszczone zostało pytanie, mogące mieć decydujące znaczenie dla rozwoju instytucji Synodu. Indaguje ono Ojców czy należy zbadać strukturę Synodu w kierunku skuteczniejszego zaangażowania biskupów w działalność kolegialną ${ }^{80}$. Doniosła jest również propozycja odnośnie stałego sekretariatu, który ma przygotowywać obrady Synodu i zabiegać wokół realizacji jego zaaprobowanych przez papieża uchwał ${ }^{81}$. Wyraźną nowością jest tu projekt komisji, dołączonej do sekretariatu, składającej się z biskupów wyznaczonych z aprobatą papieża przez Synod, pomyślanej jako pomoc dla sekretariatu i czynnik wiążący go ściśle z Synodem ${ }^{82}$.

$\mathrm{Z}$ tego ostatniego zespołu na uwagę zasługują jeszcze dwa wnioski, z których jeden zezwala biskupom na proponowanie tematyki synodalnej, a drugi ustala, że zwyczajne sesje Synodu odbywać się będą co dwa lata ${ }^{83}$. Wszystkie te wnioski przyjęte zostaly przez Synod przygniatającą, bo wahającą się w granicach 85 -90\% ilością głosów ${ }^{84}$.

Jak widać, nie doczekały się wyraźnego usankcjonowania dwa ważne dezyderaty, a mianowicie ustanowienie komisji synodalnych, paralelnych do Kongregacji rzymskich w celu zacieśnienia między nimi współpracy, oraz pominięty został projekt osobnego sekretariatu biskupów, który koordynowałby stosunki między konferencjami biskupów a urzędami papieskimi.

78 Por. Exitus..., s. 6.

79 Por. Responsiones..., s. 5.

80 J. w., s. 7.

81 Tamże. Nie od rzeczy będzie nadmienić, że selsretariat taki rzeczywiście został powołany do życia, jako konkretny owoc Synodu.

82 Tamże.

83 Tamże.

84 Por. Exitus..., s. 6. 


\section{WZAJEMNE STOSUNKI MIĘDZY KONFERENCJAMI} (HORYZONTALNY WYMIAR KOLEGIALNOSCI)

\section{Nauka dokumentów przygotowawczych}

Trzecim wielkim tematem obrad synodalnych była problematyka organicznie związana $z$ dwoma poprzednimi, określona przez Schemat przygotowawczy Synodu, jako aspekt horyzontalny kolegialności 85 . W odróżnieniu od rozdziału drugiego Schematu, skupiającego się na stosunkach między prymatem a episkopatem, rozdział trzeci zajął się równie chyba życiowo doniosłym, choć znacznie mniej od strony teoretycznej opracowanym zagadnieniem różnorakich powiązań zachodzących pomiędzy różnymi ogniwami ogólnoświatowego episkopatu ${ }^{86}$. Że powiązania takie istnieją, że istnieje bogaty rejestr ich możliwości, to nie ulega wątpliwości, ale wskazanie na teoretyczne podstawy praktycznych rozwiązań w tym względzie nie jest łatwe. Wyraziło się to dobitnie w redakcji Schematu, który zasadniczą część krótkiego zresztą rozdziału poświęcił rozważeniu tych właśnie praktycznych rozwiązań, już to istniejących, już to pozostałych do wypracowania. Ten ewidentny brak szerszej podbudowy teoretycznej w Schemacie i powiązania z kolegialnością, wyraźnie stara się uzupełnić Relacja do tego rozdziału, kilkakrotnie wskutek tego od niego większa ${ }^{87}$. I ona jednak, w sposób łatwo dostrzegalny, główny nacisk kładzie na sprawę praktycznej realizacji współpracy oraz różnorakich powiązań wewnątrz kolegium biskupiego i palącej aktualności tychże.

Punktem wyjścia dokumentów przygotowawczych dla teoretycznej podbudowy zagadnienia współpracy konferencji biskupów, jest podstawowa teza eklezjologiczna o organicznej więzi łączącej, posiadające swoją własną fizjonomię, swojego genius loci, Kościoły lokalne w pełnię Kościoła powszechnego, powierzonego pasterskiej trosce całego episkopatu ${ }^{88}$. O tej specyfice Kościoła lokalnego decyduje zespół jemu tylko właściwych dóbr i wartości, które w oparciu o powszechną odpowiedzialność apostolską biskupów, powinny zostać świadomie udostępnione, stać się własnością reszty organizmu Kościoła powszechnego, czy mogącej z tego wyciągnąc rzeczywiste korzyści jakiejś jego części. Rzecz nie może zostać w gestii spontanicznie dokonywujących się procesów spo-

85 Por. Expositio et Explicatio relationis „De Arctiore coniunctione inter ipsas Episcoporum Conferentias", Typis Polyglottis Vaticanis, 1969, s. 5: „Concilium... nec non Ecclesiae vita, amplam horizontalem mensuram harum relationum inter Episcopos omnes nostris temporibus maxime certe congruentem nobis ostendunt..."

86 Relatorem trzeciej części Schematu był biskup Panamy Kard. M. McGrath.

87 Relatio de arctiore coniunctione inter ipsas Episcoporum Conferentias, Typis Polyglottis Vaticanis, 1969.

88 Por. Rel. III, s. 6-7, Schemat, s. 27. 
łeczno-religijnych osmozy, które, jak pokazuje życie, pozostawiona sobie może działać nie tylko $\mathrm{ku}$ budowaniu, ale i ku burzeniu ogólnokościelnego dobra i jedności ${ }^{89}$. I tu właśnie ma swoją podstawę potrzeba i konieczność świadomego kierowania tymi doniosłymi procesami, nurtującymi wnętrze kościelnej społeczności, procesami które są nie do uniknięcia, które mogą i powinny stać się potężnymi współczynnikami dynamizacji życia kościelnego i jedności ${ }^{90}$. W tym miejscu włącza się drugi człon teoretycznej podbudowy współpracy międzybiskupiej. Jest nim nauka o godności biskupa, jako głównego reprezentanta i promotora, stróża dóbr i wartości stanowiących specyficzne wyposażenie Kościołów lokalnych. To on bowiem na gruncie posiadanego uczestnictwa w kapłaństwie Chrystusa-Głowy, jest w pierwszym rzędzie odpowiedzialny za tę prawidłowo przebiegającą osmozę religijnych wartości życia wewnątrzkościelnego, którą ma umożliwiać, wspomagać, ale i kierować ${ }^{91}$. Rolę tę podbudowuje jeszcze fakt przynależności każdego biskupa do wspólnoty kolegium biskupiego, obarczonego odpowiedzialnością za cały Kościół. Nakłada to na każdego członka tego kolegium obowiązek zabiegania $w$ ramach posiadanych warunków także i o dobro całego Kościoła. Jednym $\mathrm{z}$ pierwszych elementów tej ogólnokościelnej troski jest wysiłek twórczego konfrontowania rytmu życia własnego Kościoła z rytmem życia pojedynczych Kościołów sąsiadujących, czy obejmujących je instytucji konferencji biskupich ${ }^{92}$. Konferencje te stanowią w obecnym momencie zasadniczy obszar, na którym dokonuje się ten doniosły proces horyzontalnej realizacji kościelnej kolegialności.

Wyjaśniwszy teoretyczne przesłanki istnienia i działania w Kościele organizmów, w których najdoskonalszą reprezentacją są konferencje episkopatów, Relacja przedstawiająca rozdział III Schematu, skierowuje uwagę na palącą aktualność tego właśnie horyzontalnego wymiaru kolegialności. Ostrzegłszy przed niewolniczym przenoszeniem na teren życia Kościoła naturalnych zjawisk nurtujących społeczne organizmy ludzkie, a zwłaszcza przeciwko lansowanemu w nich prawu natychmiastowego skutkowania, Relacja domaga się jednak wzięcia tych zjawisk pod uwagę, upatrując w nich i poważny wymóg i cenny przykład reali-

89 Schemat, s. 27: „Haec enim sollicitudo illis qua Collegii Episcopalis membris et apostolorum legitimis successoribus competit, qui proinde bene regendo propriam Ecclesiam ut portionem Ecclesiae universae efficaciter conferunt ad bonum totius mystici Corporis, quod est etiam corpus Ecclesiarum. Ecclesiae locales varietatem unius et indivisae Ecclesiae Christi manifestant, hoc tamen non fiet sine detrimento huiuscemodi unitatis, nisi omnes Ecclesiae suis propriis donis in unitatis plenitudinem conspirent".

90 Rel. III, s. 7.

91 Rel. III, s. 6-8.

92 Schemat, s. 27. 
zacji obowiązku społecznej współpracy kościelnych organizmów, jakimi są konferencje krajowe biskupów ${ }^{93}$.

Z kolei Relacja motywuje konieczność szerokiej współpracy różnego rodzaju organizmów w Kościele faktem żywiołowego pędu współczesnej ludzkości do jedności, koordynacji i współpracy ${ }^{94}$. W konsekwencji tego faktu, konkluduje lapidarnie Relacja „wszyscy chrześcijanie powinni dbać o większa jedność w stużbie braterstwa wszystkich ludzi" ${ }^{95}$. Wymaga to przezwyciężania, głęboko w życiu chrześcijan a nawet hierarchii kościelnej zakorzenionego indywidualizmu, uchylającego się od społecznego współdziałania i zabieganie o dobro drugiego ${ }^{96}$. Postawa taka stoi $\mathrm{w}$ jaskrawej sprzeczności z prawdziwą erupcją w dzisiejszym świecie najróżnorodniejszych form społecznego współdziałania. Współdziałanie to jest więc nakazem chwili dla wszystkich członków Kościoła w różnych warstwach jego życia, ale w szczególny sposób obowiązuje ono kolegium biskupie, obarczone odpowiedzialnością za cały Kościói ${ }^{97}$. Obowiązek ten spoczywa na pasterzu odpowiedzialnym za powierzony jego pieczy Kościół, ale i za Kościoły z nim sąsiadujące, które mogą potrzebować pomocy, czy współpracy jego Kościoła ${ }^{98}$.

Najbardziej przejrzystą i skuteczną formą takiej współpracy i działania w jedności są krajowe konferencje episkopatu, usankcjonowane oficjalnie i polecone przez II Sobór Watykański ${ }^{99}$. Cenna ta instytucja zawiera ogromny wachlarz możliwości współdziałania ze sobą różnych episkopatów, które to możliwości należy koniecznie wykorzystać. Tak Schemat przygotowawczy ${ }^{100}$, jak zwłaszcza Relacja ${ }^{101}$, szeroko opisuje warianty tych możliwości, wysuwając cały szereg cennych propozycji zmierzających do efektywnego współdziałania konferencji na różnych polach ich aktywności. Omówienie tych aktualności Relacja rozpoczyna od przypomnienia ogólnej zasady kolegialnego współdziałania bi-

93 Rel. III, s. 5: „Bene scimus vitam Ecclesiae referri non posse simpliciter ad methodos hodiernas magnarum rerum moliendarum (entreprises), neque ad immediatam efficaciam eiusdem operositatis...".

94 Rel. III, s. $9-10$.

95 „Quapropter omnibus christianis onus incumbit maiorem religiosam unitatem fovendi in omnium hominum fraternitatis servitium", Rel. III, s. 9.

96 Por. Rel. III, s. 8: „Frequenter ,indifferentia” et ,individualismus” cum aliorum tum etiam noster nos praepediunt. Videtur elapsorum saeculorum ,liberalismi individualistici" contagio non tantum in nationum vitam oeconomicam sed etiam in vitam nostram religiosam fortiter irrepsisse".

97 Por. Rel. III, s. 11.

98 Por. Rel. III, s. 12: ,... Ecclesia particularis non nisi manca est et imperfecta, nisi vivam communionem cum alis Ecclesiis particularibus ineat, sic ad vitam universalis Ecclesiae conferendo, quod praecipue in hodiernis adiunctis magnum momentum habet".

99 Por. KK, III, nr 23: Dekret Christus Dominus, AAS, 58 (1966) oraz Motu proprio Ecclesiae Sanctae, AAS, 58 (1966).

100 s. 28.

101 SS. $17 \mathrm{nn}$. 
skupów i episkopatów, sformułowanej przez Konstytucję Lumen Gentium 102, oraz konkretnych sposobów takiego współdziałania, postulowanych przez inne soborowe dokumenty ${ }^{103}$. Doniosły w tym względzie dokument posoborowy, jakim jest wspomniane Motu proprio Ecclesiae Sanctae daje szereg wytycznych odnośnie struktury i wzajemnej współpracy konferencji biskupich. Jest tam więc mowa o wzajemnym komunikowaniu sobie sposobów apostolstwa, wartościowej dokumentacji, wiadomości o grożących błędach i niebezpieczeństwach ${ }^{104}$. Relacja wspomina jeszcze o sugestiach zawartych w Dekrecie Christus Dominus dotyczących ponaddiecezjalnego kierownictwa niektórych inicjatyw duszpasterskich ${ }^{105}$, oraz o gotowości służenia radą Najwyższemu Pasterzowi przez światowy episkopat ${ }^{106}$. Głównym jednak przedmiotem zainteresowania Relacji, są formy współdziałania episkopatów, które wyłoniło samo życie Kościoła po Soborze ${ }^{107}$. Dzieli ona te inicjatywy na dwie grupy. Pierwsza, stanowi to, co dosłownie określone zostało jako contactus occasionales inter Conferentias ${ }^{108}$. Chodzi tu o wspólne, ale dorywcze inicjatywy episkopatów, zmierzające do przeprowadzenia takich konkretnych akcji, jak wspólne dla określonych grup językowych tłumaczenia tekstów liturgicznych konkretnym zjawiskiem czy problemem (np. procesami migracyjnymi), konferencje odległych geograficznie episkopatów na gruncie udzielanej pomocy materialnej, czy wreszcie kontakty episkopatów zmierzające do aktywizacji międzynarodowej organizacji katolickich ${ }^{109}$.

Drugi rodzaj kontaktów między konferencjami episkopatów stanowią ponadnarodowe konferencje biskupów, powstałe w oparciu o Dekret Christus Dominus ${ }^{110}$. Konferencje takie są instytucjami stałymi, utworzonymi na gruncie już to geograficznego sąsiedztwa, już to podobieństwa warunków i sytuacji 111.

Ostatnia grupa kontaktów między episkopatami, o których wspomina Relacja, została ujęta w rubrykę: Consilium, Symposium Federatio ${ }^{112}$. Formy te różnią się od ściśle pojętych konferencji ze względu na ich charakter wyraźnie doradczy i informacyjny ${ }^{113}$. Klasyczny przykład tego

$102 \mathrm{KK}$, III, nr 23.

103 Np. Konstytucja o Liturgii (nr 22, 39); Dekret o pasterskich zadaniach biskupów (nr 6, 7, 12); Dekret o postudze i życiu kapłańskim (nr 70); Dekret o dziatalności misyjnej Kościoła (nr 38); Dekret o Ekumeniźmie (nr 4).

104 I, 41, 5.

105 Tamże.

$106 \mathrm{nr} 5$.

107 Rel. III, Ss. 18-19.

108 Rel. III, s. 19.

109 Rel. III, ss. 19-20.

$11038,5$.

111 Rel. III, s. 20.

112 Tamże.

113 Tamże, s. 21. 
typu współdziałania stanowią południowo amerykańskie organizacje ponadnarodowe episkopatów C. E. L. A. M. i C. E. D. A. L. Coś pośredniego między Consilium a konferencją, tworzą różne ugrupowania biskupów afrykańskich ${ }^{114}$. A wreszcie na uwagę zasługują sympozja biskupów europejskich, organizowane dla przedyskutowania określonej problematyki duszpasterskiej ${ }^{115}$.

Jak widać, wachlarz możliwości współdziałania biskupów, dyktowanych poczuciem odpowiedzialności za dobro całego Kościoła, jest rzeczywiście imponujący. Zadaniem jakie stoi obecnie przed Kościołem, jest nie tylko dalsze doskonalenie form już wytworzonych, ale i troska o tworzenie nowych, postulowanych przez życie i dobro Kościoła. W tym też kierunku poszła synodalna debata nad trzecim rozdziałem Schematu przygotowawczego.

\section{Treść i wynik obrad}

Żywą i obszerną dyskusję nad trzecim rozdziałem Schematu i prezentująca go Relacją, podsumował kolejny sekretarz soborowy biskup R. Etchegaray ${ }^{116}$. Dopatrzył się w niej dwu nurtów tematycznych: teologicznego i praktycznego. Pierwszy, obejmujący jego zdaniem pięc głównych zagadnień miał, rzecz jasna, charakter teoretyczny. W rzeczy samej, tak samo zasadnicze zagadnienie kolegialności horyzontalnej, jak i szereg wypowiedzi Ojców synodalnych, wyraźnie nawiązywało do problematyki teoretycznej i teologicznej. Stwierdził to na początku pierwszej części swej wypowiedzi wspomniany sekretarz: „konieczność ściślejszej tączności między samymi konferencjami biskupów, jest dla wszystkich oczywista. Konieczność ta opiera sie nie tylko na rozważaniach o charakterze pastoralnym, ale przede wszystkim na doktrynie o kolegialności" 117. Stwierdzenie to posiada doniosłe znaczenie z punktu widzenia tak doktryny o kolegialności jak i związanego z tym Nadzwyczajnego Synodu Biskupów. Jego celem było wyjaśnienie i ukazanie właściwej perspektywy aktualizacji t€oretycznej zasady odpowiedzialności kolegium biskupów za cały Kościół. Rozdział trzeci Schematu nie tylko więc podaje szereg możliwości działania i współdziałania ze sobą poszczególnych episkopatów, ale wszystko to ukazuje jako wyraz i owoc przeżywanego przez biskupów affectus collegialis ${ }^{118}$. Ta ogólna i bez-

114 Rel. III, ss. $21-22$.

115 Tamże.

116 Responsiones Exc.mi D. Rogeri Etchegaray, Secretarii specialis ad animadversiones "De arctiore coniunctione inter ipsas Episcoporum Conferentias", Typis Polyglottis" Vaticanis, 1969.

117 Responsiones, III, s. 3.

118 Por. Responsiones, III, s. 3: „Vera tamen incitatio ad arctiorem coniunctionem inter Episcopos impulsum accipit ex affectu collegiali...". 
sporna zasada nie eliminuje wielu wątpliwości i niejasności, stających na drodze praktycznej realizacji. Jedną $\mathrm{z}$ tych trudności wysuwanych przez Ojców jest niesprecyzowane teologicznie i jurydycznie pojęcie konferencji biskupów ${ }^{119}$. Innym problemem, na który zwracano uwagę jest potrzeba organicznej łączności i współpracy z konferencjami biskupów z resztą społeczności kościelnej, której konferencje są swoistą reprezentacją 120. A wreszcie odzywały się głosy przestrzegające przed niebezpieczeństwem uniformizmu, godzącego w konieczną dla Kościoła różnorodność, mającą mieć z najgłębszej ich natury oparcie właśnie w konferencjach biskupów ${ }^{121}$. Także nie bez znaczenia dla kolegialności horyzontalnej jest respektowanie powagi papieża, która jest skutecznie zaangażowana w funkcjonowanie Kościołów lokalnych, czy ich zespołów ${ }^{122}$.

Jeśli chodzi o postulaty Ojców o charakterze praktycznym, sekretarz zwrócił uwagę na fakt, że wiele $\mathrm{z}$ nich zawartych jest $\mathrm{w}$ różnych dokumentach soborowych i posoborowych. Nie zostały one zrealizowane $z$ różnych powodów, dlatego dobrze się stało, że Synod stał się okazją, żeby je przypomnieć. I tak apelowano o większe zaangażowanie duchowe i materialne dla Kościołów misyjnych, jak również o wysiłki w celu większego łączenia się w większe zespoły episkopatów, aż do zespołów o wymiarach poszczególnych kontynentów ${ }^{123}$. A dalej sugerowano poszukiwania wzorów w patriarchalnych elementach ustroju Kościołów wschodnich, wprowadzanie systematycznych modyfikacji i korektur w prawnej strukturze konferencji, w czym pomocnym mógłby być powiększony Sekretariat i systematyczny serwis informacyjny 124. Zastanawiano się wreszcie nad sposobami włączenia $w$ pracę konferencji różnych organizmów katolickich grupujących księży, zakonników i świeckich. Ostatnie dwa postulaty odnotowane przez sekretarza, skierowane są do biskupów, żeby oddziaływali na kler i wiernych w kierunku uwrażliwienia ich na papieskie inicjatywy zmierzające do ulżenia ubogim i do rozwoju społeczno-ekonomicznego ${ }^{125}$.

Swoistym ukoronowaniem, a zarazem ważną przesłanką oceny debaty synodalnej nad trzecim rozdziałem Schematu, było głosowanie nad pięcioma propozycjami, streszczającymi w pewnym sensie jej dorobek. W propozycjach tych znajduje się apel - przypomnienie o pomocy materialnej dla misji, zachęta do współdziałania konferencji w oparciu

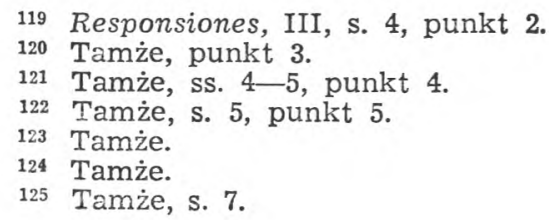


o różne punkty styczne, jakie między nimi istnieją ${ }^{126}$. Propozycja trzecia zmierza do nawiązania współpracy między konferencjami biskupów i organizacjami kościelnymi laickimi i zakonnymi ${ }^{127}$. Czwarta nawołuje do współdziałania $\mathrm{z}$ inicjatywami papieskimi w zakresie rozwoju społecznego i gospodarczego narodów opóźnionych cywilizacyjnie 128. A wreszcie piąta zawiera dezyderat udostępnienia konferencjom biskupów całej dokumentacji debaty synodalnej na temat współdziałania konferencji biskupów między sobą, a to w celu głębszego przeanalizowania tego ważnego zagadnienia ${ }^{129}$. Zasygnalizowane propozycje zawierają oczywiście drobną tylko część bogatego wachlarza projektów, jakie wysunięte zostały przez relatora tego rozdziału, a następnie przez dyskutantów. Dowodzi to, że choć zasada kolegialności horyzontalnej w jak najszerszym zakresie jest bezsporna, to praktyczne sposoby takiej realizacji nie są łatwe do wypracowania. Głosowanie na wysunięte propozycje dało wynik właściwie jednoznaczny, bo prawie 95\% głosów wypowiedziało się za ich przyjęciem ${ }^{130}$.

\section{PRÓBA OCENY DOROBKU DOKTRYNALNEGO II SYNODU}

W niniejszej próbie bilansu pominięte zostaną dotykalne efekty Synodu, wyrażające się $\mathrm{w}$ określonych decyzjach papieskich zmierzających do jego praktycznego usprawnienia. Uwaga natomiast skupiona zostanie na momentach doktrynalnych, teoretycznych prac Synodu, gdyż mimo wszystko one - jak się zdaje - stanowią ostatecznie glówne przesłanki poprawnej oceny jego trwałej wartości.

Orientacja II Synodu była w głównym swoim nurcie orientacją praktyczno-pastoralną. W założeniu chodziło mniej o wypracowanie nowych sformułowań doktrynalnych, a bardziej o konkretne rozstrzygnięcia natury organizacyjnej i duszpasterskiej. Synod Biskupów jednak jest już dzisiaj w życiu Kościoła wydarzeniem tak doniosłym, że jego skutki nie dadzą się zamknąć w jednej kategorii zjawisk. Co więcej w wypadku Synodu Nadzwyczajnego wydaje się, że zasadnicze osiągnięcia nie leżą w płaszczyźnie, $\mathrm{z}$ myślą o której przede wszystkim został on zwołany. Wszystko wskazuje na to, iż zapisze się on w historii Kościoła przede wszystkim dzięki jego doktrynie oraz związanym $\mathrm{z}$ nią świadectwem wiary i świadomości Kościoła.

126 De Arctiore Coniunctione inter ipsas Episcoporum Conferentias. Exitus Manifestationis Sententiae cum Recensione Modorum Propositorum, Typis Polyglottis Vaticanis 1969 , s. $1-8$.

127 Tamże, s. 10.

128 Tamże, s. 12.

129 Tamże, s. 13.

130 Tamże, s. 6. 
Mimo, że od zakończenia Synodu upłynęło już parę miesięcy, to przecież wydaje się, że nie nadszedł jeszcze czas żeby podjąć próbę wyczerpującej oceny jego dorobku. $\mathrm{Z}$ tego względu niniejsza podsumowująca wypowiedź ograniczy się do zasygnalizowania najbardziej oczywistych osiągnięć synodalnych w zakresie doktryny o kolegialności.

\section{DEFINITYWNA APROBATA KOLEGIALNOSCI JAKO KOSCIELNEJ STRUKTURY ORGANIZACYJNEJ}

Sobór Watykański II szeregiem doniosłych stwierdzeń dotyczących głównie episkopatu, stworzył przesłanki dla tego, co zwykło się określać mianem kolegialności. Były to jednak tylko przesłanki, z których najważniejsze to: zasada odpowiedzialności kolegium biskupiego za cały Kościół i związana $\mathrm{z}$ nią ściśle zasada najwyższego i powszechnego zwierzchnictwa tegoż kolegium w Kościele. Wprawdzie Dekret Christus Dominus podejmuje pewne próby wyciągania praktycznych wniosków z powyższych przesłanek, niemniej są to próby bardzo nieśmiałe i co ważniejsze nie wiążące wyraźnie tej pewnej aktywizacji episkopatu z kolegialnością. Jest to o tyle słuszne, że kolegialność, jako określona forma rządów w Kościele, nigdzie w dorobku soborowym wyraźnie nie została wymieniona. Przede wszystkim została pominięta milczeniem $\mathrm{w}$ magistralnym dokumencie eklezjologicznym, jakim jest Konstytucja o Kościele.

Na tym tle II Synod Biskupów jest wydarzeniem o znaczeniu przełomowym. Głównym i jedynym bowiem przedmiotem jego uwagi było nie co innego, a właśnie kolegialność in praxi, a więc określona forma kierowania Kościołem, bazująca na usankcjonowanych w Lumen Gentium ogólnokościelnych prerogatywach episkopatu. Ta tendencja Synodu otrzymała konkretny wyraz w oficjalnym placet Kościoła dla samego terminu. Już w przemówieniu inauguracyjnym Paweł VI użył go aż osiem razy, obejmując tą nazwą bogaty wachlarz aktywności episkopatu w Kościele na czele z Synodem biskupów ${ }^{132}$. Jeszcze dobitniej, sankcjonuje tak nazwę jak i treść kolegialności, stanowiący podstawę prac synodu, Schemat przygotowawczy. „W konsekwencji - jak powie słusznie jeden $\mathrm{z}$ autorów - tak nazwa, jak sama idea kolegialności, zostały przyjęte w całym Kościele. Vaticanum II zaś stał się definitywnie soborem kolegialności, jak Vaticanum I było soborem papiestwa" ${ }^{13 \mathbf{3}}$.

131 Por. R. Laurentin, Le prémier Synode, histoire et bilan, Paris 1968, ss. 245-7.

132 G. Caprile, Il Sinodo dei Vascovi 1969, Roma 1970, ss. 61-62.

133 O. Rousseau, Le deuxième Synode des évêques. Collegialité et Communion, „Irenikon”, 4 (1969) 465-466. 


\section{PIERWSZA PRÓBA GEĘBSZEJ SYNTEZY NAUKI O KOLEGIALNOŚSI}

Kolegialność jako kategoria eklezjologiczno-ustrojowa, stanowi rzeczywistość równie bogatą co trudną do adekwatnego określenia. We wzmiankowanym już przemówieniu inauguracyjnym Paweł VI wymownie to stwierdzi: „A więc... istnieje między nami, wybranymi na następców apostolskich szczególna więź, więź kolegialności. A cóż to jest kolegialność, jeżeli nie wspólnota, solidarność, braterstwo, miłość... Kolegialność jest współodpowiedzialnościa" ${ }^{134}$. Synod potwierdził w całej rozciągłości bogactwo treściowe kolegialności, obejmując nią nie tylko różnoraki współudział biskupów w kierowaniu całym Kościołem (kolegialność wertykalna) ale i szerokie współdziałanie biskupów w pasterskiej trosce o Kościoły lokalne, czy ich mniejsze lub większe zespoły. Stanowi to moment o dużej doniosłości. Kolegialność bowiem dość często sprowadzano $\mathrm{w}$ ciasne ramy ogólnokościelnego zwierzchnictwa biskupów. Synod, nie eliminując zwierzchnictwa takiego z kolegialności, wylicza szereg innych jej elementów składowych, takich jak jedność biskupów z papieżem i między sobą, wzajemna i prawdziwa miłość, koordynacja pasterskiej troski o Kościół, szeroka współpraca w realizacji tej troski, czy wreszcie szerokie stosowanie konsultacji. Jest jasne, że Synod nie wyczerpał jeszcze, ani adekwatnie nie scharakteryzował tego, co na kolegialność się składa. Tym niemniej po raz pierwszy oficjalnie ukazał jej treść w istotnych elementach, wyraźnie zakreślając jej ramy.

Zasługa Synodu nie ogranicza się tylko do próby określenia pojęcia kolegialności. Usiłował on bowiem $\mathrm{z}$ jednej strony wskazać na najgłębsze jej źródła w życiu Kościoła, jakie stanowi z jednej strony dynamicznie ujmowana wspólnotowość Kościoła, a $\mathrm{z}$ drugiej należąca do jego najgłębszej istoty katolickość. Do tego dodać należy jej źródło bliższe, o konkretnym zabarwieniu psychologiczno-religijnym, jaki stanowi, nieznana dotąd $\mathrm{w}$ literaturze teologicznej a powszechnie niemal zaakceptowana kategoria affectus collegialis. Tak odważne ujęcie istoty kolegialności, jak zwłaszcza umieszczenie jej w niezmiernie bogatym treściowo kontekście idei wspólnoty, stanowi niewątpliwie decydujący krok w kierunku właściwego jej zrozumienia i ujęcia ${ }^{135}$.

\section{KOLEGIALNY CHARAKTER ZWIERZCHNICTWA KOSCIELNEGO}

Kolejne wartościowe novum II Synodu dotyczy, posiadającego niewątpliwie pierwszoplanowe znaczenie w kolegialności, zagadnienia charakteru jurysdykcyjnego zwierzchnictwa kościelnego. Zwierzchnictwo

134 Por. Caprile, dz. cyt., s. 61.

135 Por. Rousseau, art. cyt., ss. $469-471$. 
to jak wiadomo nie jest zjawiskiem jednolitym, ale stanowi nie mającą odpowiednika w stosunkach świeckich kombinację ustrojową, na którą składa się jednostkowa władza Następcy Piotrowego i zespołowe zwierzchnictwo następców grona apostolskiego biskupów. Autentyczna teologia katolicka nigdy nie zacieśniała najwyższego zwierzchnictwa kościelnego do jednostkowej, absolutnie monarchicznej władzy papieskiej, nie zawsze jednak wystarczająco uwypuklała rolę episkopatu. Obydwa ostatnie Sobory ustaliły teoretyczne zasady prawidłowego zespolenia dwu pozornie antagonistycznych, a w rzeczywistości komplementarnych elementów kościelnego zwierzchnictwa. II Nadzwyczajny Synod Biskupów podjął pracowitą próbę możliwie dokładnego przeanalizowania tego komplementarnego charakteru elementów składowych władzy w Kościele. W zasadzie doktryna Synodu usiłowała mieścić się w szrankach nauki pierwszego i drugiego Soboru Watykańskiego. W jednym jednak doniosłym punkcie zrobiono poważny krok naprzód. Dotyczy to zagadnienia kolegialnego charakteru całego zwierzchnictwa kościelnego.

Wiadomo, że władza papieska posiada immunitet w pełni niezależnego działania i decydowania w Kościele, wiadomo że taki immunitet jest dla Kościoła niezbędnie potrzebny, wiadomo wreszcie że posiada on własny niemożliwy do zastąpienia rytm funkcjonowania w życiu Kościoła. $\mathrm{Z}$ drugiej jednak strony jest rzeczą bezsporną, że prymat papieski istnieje dla Kościoła i w Kościele (co nie wyklucza bynajmniej, że w pewnym sensie jest i ponad Kościołem). Co więcej II Sobór Watykański zwrócił uwagę na fakt organicznego związku prymatu $\mathrm{z}$ kolegium biskupim. Synod podjął ten delikatny problem więzi istniejących między zwierzchnictwem papieskim i biskupim w Kościele i wysunął sugestie, które oznaczają poważny zwrot w ujmowaniu wzajemnego stosunku tych dwu elementów składowych kościelnego zwierzchnictwa. Stanął bowiem na stanowisku, że nawet wtedy, kiedy papież działa sam; jako najwyższy zwierzchnik Kościoła, pozostaje on w łączności z kolegium biskupów. Oznacza to konsekwentnie, że zwierzchnictwo kościelne traktowane jest jako jeden organicznie zrośnięty mechanizm, którego prawidłowe funkcjonowanie uwarunkowane jest zaangażowaniem obydwu składających się na nie członów. Oczywiście zaangażowanie to realizować się będzie stosownie do specyficznej struktury obydwu elementów składowych kościelnego zwierzchnictwa, tym niemniej zaangażowanie żadnego z tych elementów nie może być świadomie eliminowane, owszem winno się wyraźnie uzewnętrzniać.

Nietrudno dostrzec, że zagadnienie jest i bardzo skomplikowane, i bardzo doniosłe. Stanowisko wszakże zajęte przez Synod dobitnie pokazuje, w jakim kierunku ewoluuje w tej sprawie oficjalny pogląd Kościoła. 


\section{KOLEGIALNOSC SYNODU BISKUPÓW}

Zespołowy, w swej najgłębszej istocie, charakter kościelnego zwierzchnictwa, rodzi potrzebę zespołowego działania, w którym ta specyficzna struktura władzy $w$ Kościele znalazłaby naturalny wyraz, a zarazem okazję do korzystnej interwencji w życie Kościoła. II Synod Biskupów miał na celu przede wszystkim, ażeby takie właśnie działanie wzmóc w sensie jakościowym i ilościowym. Tego rodzaju nastawienie kazało się spodziewać że w pierwszym rzędzie zwróci się uwagę na te odcinki działalności kościelnej, w których kolegialny charakter występuje szczególnie wyraźnie i zadba się o to, by charakter ten sprecyzować. W szczególny sposób odnosiło się to do samej instytucji Synodu, który według dotychczas obowiązującego prawodawstwa jest organem doradczym papieża, a więc instytucją związaną bardziej z praktyką funkcjonowania prymatu, aniżeli kolegium biskupiego. Oczywiście, mając na uwadze poruszoną co dopiero sprawę głębokiej spójności całej aktywności kościelnej zwierzchnictwa doradczy charakter Synodu mieści się w kolegialności. Niemniej Synod od początku świadomości katolickiej narzucał się jako klasyczny przejaw działania kolegialnego w dobie międzysoborowej, w której struktura kolegialna Kościoła jest stale istniejącym i mającym zapotrzebowanie na realizację prawem. Toteż nic dziwnego, że wyrażano nadzieję, iż organizacyjny profil Synodu na obecnej jego sesji ulegnie zrewidowaniu. I tu można mówić o pewnym zawodzie, jaki sprawił II Synod. Miał być przecież Synodem kolegialności, a tymczasem nie posunął w niczym naprzód sprawy nadania tej instytucji charakteru ściśle kolegialnego. Został on bowiem nadal organem doradczym papieża, a więc czynnikiem opiniodawczym, a nie prawodawczym. Zapewne istaniały powody, żeby sprawę tę zostawić jeszcze w zawieszeniu, tym niemnej faktem pozostaje, że krok, który wydawało się, że na pewno zostanie zrobiony, zrobiony nie został.

\section{„KOLEGIALNOŚĆ HORYZONTALNA”}

Już sam termin „kolegialność horyzontalna” stanowi wartościowe novum w ubogiej nomenklaturze kolegialności. Dobrze charakteryzuje on spory wycinek działalności kolegialnej, wyraźnie oddzielając go od tego, co równie trafnie określone zostało jako „kolegialność wertykalna”. Oczywiście, że i te nazwy dalekie są od doskonałości, wydaje się jednak, że na pewien czas mogą być bardzo przydatne przy badaniu i wyjaśnianiu zawartości treściowej kolegialności.

Znacznie większe znaczenie od aspektu terminologicznego posiada aspekt merytoryczny tego sformułowania. Składa się na niego przede 
wszystkim włączenie sporego obszaru różnorodnej działalności episkopatu światowego do kolegialności kościelnej. Dzieki temu widać naocznie, że kolegialność w pewnym stopniu była w Kościele zawsze, bo zawsze realizowała się jakaś zespołowa odpowiedzialność biskupów za życie kościelne.

Godnym jednak szczególnego podkreślenia jest akcent, jaki Synod położył na troskę i odpowiedzialność biskupów za życie kościelne, realizujące się poza granicami własnych Kościołów. Biskup zdaniem Synodu nie może się zamknąc $w$ ciasnych ramach swojego Kościoła, ale nawiązując różnorakie relacje z Kościołami ościennymi, winien być gotów do przekazywania na ich użytek tych wartości swojego Kościoła, które mogą być pomocne gdzie indziej, a których on właśnie jest piastunem i reprezentantem.

Z tym apelem Synodu o wyjście biskupów z izolacji, ściśle wiąże się postulat i gorąca zachęta, ażeby doskonalić stare i tworzyć nowe organy współdziałania różnych ugrupowań światowego episkopatu. W dobie osiągania na różnych polach wspaniałych rezultatów w wyniku zespołowego działania, Synod uważa słusznie za nakaz chwili, rozwijanie zwłaszcza na terenie tak społecznie zdeterminowanego tworu jakim jest kolegium biskupów, różnych form zespołowego działania. Nie ulega wątpliwości, że istnieje jakiś szereg problemów, których rozwiązanie możliwe jest tylko w oparciu o szeroki wachlarz doświadczeń innych ludzi, czy innych zespołów. Tak samo działanie dobra, może być wybitnie zwielokrotnione w swojej skuteczności, przy zastosowaniu społecznego współdziałania.

Zasygnalizowane powyżej osiągnięcia II Nadzwyczajnego Synodu Biskupów, nie obejmują na pewno wszystkiego, co nazwą taką można określić nawet w tak zacieśnionym wymiarze, w jakim usiłowano dokonać powyższego podsumowania. Już jednak tak przeprowadzony bilans świadczy o dużej doniosłości II Nadzwyczajnego Synodu Biskupów. Gdy zaś do tego dodać jeszcze klimat głębokiej jedności panującej między jego uczestnikami, jednomyślną aprobatę zasady kolegialności i głęboką troskę o jej efektywną realizację, a wreszcie dalsze praktyczne decyzje zmierzające do usprawnienia funkcjonowania Synodu - to nie będzie przesadą uznanie go za dużej miary wydarzenie w życiu Kościoła. 


\section{R E S U M E}

\section{LA DOCTRINE DU SYNODE}

Les motifs, qui d'après les documents du Synode, en ont causé la convocation, étaient les suivants: la croissance du sens de la responsabilité de la vie de l'Eglise, le piétisme envers la doctrine de Vatican II, la nécessité d'adaptation des institutions ecclésiastiques à la vie d'aujourd'hui et enfin le souci de réalisation du principe de la collégialité et, par conséquent, de l'unité des évêques avec le pape.

Le premier chapitre du Schéma, qui doit servir de base doctrinale aux conclusions pratiques, s'efforce de présenter un ensemble sûr et précis des données théologiques de la doctrine de la collégialité, tirant son origine des décisions des deux derniers Conciles. Son point de départ est la doctrine de l'Eglise, communauté surnaturelle, dont l'élément essentiel, à côté d'autres biens surnaturels, est constitué par la tendance organique à une multiple action commune. Dans l'ensemble de la communauté ecclésiale, existe et fonctionne la communauté de la souveraineté religieuse, constituée par le collège des évêques avec le pape, sa tête. Ce collège, participant au charisme épiscopal, est appelé à une harmonieuse coopération dans l'exercice d'une autorité au service de l'Eglise. Bien qu'elle soit nécessaire et indispensable, cette coopération n'est pas facile à réaliser. étant donnée la structure spécifique et le rôle de la primauté et du collège épiscopal dans la responsabilité hierarchique de l'Eglise, mentionnée plus haut. Cependant, il faut que ces deux éléments soient conservés dans la vie de l'Eglise, car, entre autres, ils constituent pour elle la source de ses attributs, tels que l'unité et l'universalité. L'activité de la primauté ainsi que du collège épiscopal doit respecter les normes objectives qui naissent de la nature même de l'autorité ecclésiastique constituée par le Christ. Le rôle du pape, tout en conservant une suprématie effective, consiste à admettre, inspirer et coordonner l'activité collégiale des évêques, qui, à travers les formes d'action collégiale ,stricto sensu", prend, le plus souvent, une forme qui en est plus ou moins rapprochée.

Le deuxième chapitre du Schéma traite des formes concrètes de la coopération du collège épiscopal avec le pape, par l'intermédiaire des conférences épiscopales (la collégialité verticale). Après l'énumération des motifs actuels, qui ordonnent une telle coopération, on a mis en avant une série de propositions qui ont pour but de resserrer effectivement la collaboration entre le Siège Apostolique et les conférences des évêques, et d'autre part, à améliorer la structure et l'organisation du Synode. A la fin des débats synodaux on a formulé, en treize points, les conclusions, qui ont été acceptées à la majorité des voix.

Le troisième sujet des débats synodaux est constitué par le problème des liens existants entre les différents groupes épiscopaux du monde antier, et par les possibilités d'une vaste collaboration entre eux. Dans la première partie de ce chapitre on attire l'attention sur la base théorétique et sur les raisons actuelles de cette collaboration. La note de l'universalité de l'Eglise, avec son caractère communautaire postulant un échange permanent des valeurs possédées par les Eglises particulières, est la source du principe de la coopération de l'épiscopat. Un tel échange, s'exprimant concrètement dans la sollicitude des évêques pour les Eglises voisines, conditionne un soin fructueux de leur propre Eglise. L'immense élan de l'humanité contemporaine à l'unité de coordination et de collaboration, pousse d'autant plus à ce genre de collaboration. Cette tendance à l'unité s'affirme dans ses fruits innombrables, c'est une raison de plus de l'imiter dans l'Eglise. 
La deuxième partie du dernier chapitre est consacrée à la recherche des procédés pratiques qui pourraient développer la collaboration de différentes sortes d'organisations de l'Episcopat mondial avec, à la tête, les conférences épiscopales des pays. Le débat s'est terminé par le vote de cinq propositions, qui ont été acceptées à une majorité de voix écrasante.

Une évaluation première des résultats du Synode attire l'attention, avant tout, sur l'approbation officielle par l'Eglise de la collégialité en tant que structure ecclésialogique ainsi que sur l'essai officiel de créer une synthèse doctrinale de cette structure. Deux éléments suivants sont constitués par l'affirmation du caractère collégial de la souveraineté ecclésiastique dans toute son étendu et par une forte insistance sur la collaboration des évêques au sein de l'épiscopat mondial comme symptôme de la collégialité ecclésiastique. On souligne, en terminant, la nécessité de garder au Synode épiscopal son caractère consultatif. 